\title{
AUTHOR INDEX Volume 7
}

Barreria, J., see Urban, B.

4 (2010) 329

Beach, R., see Judi, H. M.

2 (2010) 161

Bhutto, A., see Moinuddin, Q. M.

4 (2010) 377

Blume, V., see Grienitz, V.

3 (2010) 237

Braet, J., see De Cleyn, S. H.

1 (2010) 53

Budde, O., see Golovatchev, J.

3 (2010) 229

Buse, S., Tiwari, R. \& Herstatt, C., Global Innovation: An Answer to Mitigate Barriers to Innovation in Small and Medium-Sized Enterprises?

$3(2010) 215$

Chang, T.-J., Chen, W.-C., Lin, L. Z. \& Chiu, J. S.-K., The Impact of Market Orientation on Customer Knowledge Development and NPD Success

Chen, W.-C., see Chang, T.-J.

Chiu, J. S.-K., see Chang, T.-J.

Chung, H.-J., see Hsieh, T.-J.

Corkindale, D., Towards a Business Model for Commercializing Innovative New Technology

De Cleyn, S. H. \& Braet, J., The Evolution of Spin-Off Ventures: An Integrated Model

Einspruch, N. G., see Omachonu, V. K.

Geisler, E., Measuring the Contributions of Knowledge Management Systems to the Strategic Competitiveness of Organizations:

A Review and a Model

$2(2010) 89$

Golovatchev, J., Budde, O. \& Kellmereit, D., Technology and Innovation Radars: Effective Instruments for the Development of a Sustainable Innovation Strategy and Successful Product Launches

Grienitz, V. \& Blume, V., Strategic Planning of Future Products with Product Scenarios

Hampden-Turner, C., see Zhou, Y.

3 (2010) 273

Herstatt, C., see Buse, S.

3 (2010) 215

Hsieh, T.-J., Chung, H.-J. \& Lo, H., The Impact of Top Management Team Conflict on New Product Development: A Cross-Cultural Perspective

Hull, C. E., see Luxmore, S. R. 
Jaafar, N. I., see Sulaiman, A.

$2(2010) 129$

Jani, R., see Sulaiman, A.

2 (2010) 129

Janzik, L., Contribution and Participation in Innovation Communities:

A Classification of Incentives and Motives

3 (2010) 247

Jiang, W. Y., Quan, X. \& Zhou, S., Historical, Entrepreneurial and

Supply Chain Management Perspectives on the Semiconductor

Industry

Judi, H. M. \& Beach, R., Achieving Manufacturing Flexibility: The Role of People, Technology, Innovation and Continuous Improvement

Kaiser, L., Management of Intellectual Property in Research and Development: A Search for Systems from the Viewpoint of

Research and Technology Organizations

Kellmereit, D., see Golovatchev, J.

Khanna, V. K., An Indian Experience of the Environmental Management System

Lai, W.-H. \& Tsai, C.-T., Analyzing Influence Factors of Technology Transfer Using Fuzzy Set Theory

Lin, L. Z., see Chang, T.-J.

Lo, H., see Hsieh, T.-J.

Luxmore, S. R. \& Hull, C. E., Externalities and the Six Facets Model of Technology Management: Genetically Modified Organisms in Agribusiness

1 (2010) 19

Minshall, T., see Zhou, Y.

3 (2010) 273

Moinuddin, Q. M., Rashdi, P. I. S. \& Bhutto, A., Innovations in Nanotechnology Organizations

$4(2010) 377$

Narayanapillai, R., An Evaluation of Inventory Management and Performance in Indian Machine Tool SMEs: An Exploratory Study

Nasierowski, W., Technical Efficiency of Efforts to Enhance Innovativeness in the European Union

Omachonu, V. K. \& Einspruch, N. G., Innovation: Implications for Goods and Services

Pohl, H., Interparadigmatic Hybrids: A New Theoretical Concept When Addressing Paradigmatic Shifts in Technology

Quan, X., see Jiang, W. Y.

Rashdi, P. I. S., see Moinuddin, Q. M.

3 (2010) 263

3 (2010) 229

$4(2010) 423$

1 (2010) 71

4 (2010) 303

2 (2010) 193

$4(2010) 405$

4 (2010) 389

2 (2010) 109

4 (2010) 353

1 (2010) 1

4 (2010) 377

Sulaiman, A., Jaafar, N. I. \& Jani, R., Diffusion of Information Communication Technology (ICT) Through the Rural Internet Centre: The Malaysian Experience

Tiwari, R., see Buse, S.

3 (2010) 215

Tsai, C.-T., see Lai, W.-H.

1 (2010) 71

Urban, B. \& Barreria, J., Empirical Investigations into Firm Technology Orientation and Entrepreneurial Orientation

Walwyn, D. R., Perspective: Determining Research and Development Expenditure Targets Based on an Affordability Index 
Yu, F.-L. T., Innovation in Artworks and Its Reception:

A Phenomenological Approach

$2(2010) 145$

Zhou, S., see Jiang, W. Y.

1 (2010) 1

Zhou, Y., Minshall, T. \& Hampden-Turner, C., Building Innovation

Capabilities: An Inquiry into the Dynamic Growth Process of

University Spin-Outs in China

3 (2010) 273 